\title{
The International Politics of Harmonization: The Case of Capital Market Regulation
}

\section{Citation}

Simmons, Beth A. 2001. The international politics of harmonization: The case of capital market regulation. International Organization 55(3): 589-620.

\section{Published Version}

http://dx.doi.org/10.1162/00208180152507560

\section{Permanent link}

http://nrs.harvard.edu/urn-3:HUL.InstRepos:3382976

\section{Terms of Use}

This article was downloaded from Harvard University's DASH repository, and is made available under the terms and conditions applicable to Other Posted Material, as set forth at http:// nrs.harvard.edu/urn-3:HUL.InstRepos:dash.current.terms-of-use\#LAA

\section{Share Your Story}

The Harvard community has made this article openly available.

Please share how this access benefits you. Submit a story.

\section{Accessibility}




\title{
The International Politics of Harmonization: The Case of Capital Market Regulation
}

\author{
Beth A. Simmons
}

The vast expansion of international financial activity over the last decade has been a central fact of international economic life. Balance-of-payments statistics indicate that cross-border transactions in bonds and equities among the G-7 countries rose from less than 10 percent of gross domestic product (GDP) in 1980 to over 140 percent in $1995 .{ }^{1}$ International bond and equity markets have reached staggering proportions: by the end of 1997 , portfolio holdings of equity and long-term debt securities reached nearly $\$ 5.2$ trillion. $^{2}$ Capital flows to developing countries and countries in transition grew from $\$ 57$ billion in 1990 to over $\$ 286$ billion in 1997 before plummeting to $\$ 148$ billion in 1998 . $^{3}$ Foreign exchange transactions reached an estimated average daily turnover of nearly $\$ 1.5$ trillion in 1998 compared with a daily turnover of $\$ 590$ billion in $1989 .{ }^{4}$ The annual turnover in derivatives contracts-financial agreements that derive their value from the performance of other assets, interest or currency exchange rates, or indexes-was valued at $\$ 3.4$ trillion in $1990 .^{5}$ In 1998, trading and derivatives activities of seventy-one of the world's leading banks and securities firms totaled more than $\$ 130$ trillion. $^{6}$

I thank Vinod Aggarwal, David Andrews, Michaela Dabringhausen, Jeffry Frieden, Robert Kagan, Miles Kahler, Robert Keohane, Peter Lange, Robert Pahre, Louis Pauly, Robert Powell, David Vogel, Steven Weber, Nicholas Ziegler, the two editors of $I O$, and two anonymous reviewers for useful comments on earlier versions of this article. Research was accomplished primarily while on an International Affairs Fellowship sponsored by the Council on Foreign Relations, during which time I worked in the Capital Markets and Financial Studies Division of the International Monetary Fund. Final research was completed with financial support from the Abigail Reynolds Hodgen Publication Fund Award, University of California. Support from these institutions is gratefully acknowledged. Thanks to Aaron Staines and Kirsten Rodine for excellent research assistance.

1. Figures exclude the United Kingdom.

2. IMF Global Portfolio Investment Survey, available at $\langle$ http://www.imf.org/external/np/sec/nb/2000/ NB0008.HTM $>$ (accessed May 2000).

3. International Monetary Fund (IMF) 1999, chap. 2, box 2.2.

4. Bank for International Settlements (BIS) 1998b.

5. BIS, various years, and ISDA statistics.

6. BIS 1999. 
Global capital markets pose dilemmas for national financial regulators. On the one hand, financial liberalization and the removal of capital controls calls for the sophisticated "re-regulation" of capital markets. ${ }^{7}$ Liberalization has increased competition in banking, which in turn has encouraged some firms to take on more risk. Innovative financial instruments and strategies and accounting and reporting standards that are difficult to compare across jurisdictions have compromised transparency. As capital controls have been lifted, the opportunity to use international markets for illicit activities has increased. ${ }^{8}$ On the other hand, national regulatory authorities are finding it increasingly difficult to achieve their purposes unilaterally. ${ }^{9}$ The speed with which international transactions take place, the complex structure of many financial contracts, and the multi-country network of branches and affiliates through which these transactions pass often impede efforts of national authorities to properly supervise and regulate financial markets. Competitive concerns are also important. As in other areas of economic activity, national regulators typically prefer to avoid rules that raise costs for national firms or that encourage capital or financial activity to migrate to underregulated jurisdictions.

Efforts to coordinate national policies for regulating specific aspects of international capital markets have cropped up repeatedly since the mid-1980s. They have varied in their degree of politicization and mode of institutionalization. I provide a framework to explain such variation, focusing especially on the mechanisms that encourage convergence across various areas of financial regulation. Many of our traditional theories are not especially well suited to explaining this variation. Theories of "races to the bottom," for example, are of little help. They suggest that mobile capital will lead to competition in regulatory laxity across national jurisdictions, as governments vie for footloose capital, try to attract financial business, and attempt to grant competitive advantages to national firms. The predicted result is market-induced downward pressures on regulatory standards. It is difficult, however, to reconcile this simple competitive mechanism with the general tightening of regulatory standards in a number of areas. Capital adequacy requirements for banks provides one example.

Nor are prevalent theories of cooperation very useful in explaining the variance we see in the role and strength of international institutions in this area. If international institutions are created to reduce uncertainty and transactions costs,${ }^{10}$ why are they much less developed in the regulation of financial markets than in trade? According to this argument, the volatility and volume of transactions should make financial regulation a good candidate for institutionalization. But cooperative arrangements to create common capital market regulations are far less formal, comprehensive, and inclusive than those for trade.

9. For a summary of the basic purposes of financial regulation, see Herring and Litan 1995, 50.

10. Keohane 1984. 
Finally, contrary to arguments that underlie neoliberal institutionalism, the international arrangements that have developed are not uniformly Pareto-superior to uncoordinated national policies. Some governments have resisted "harmonized" regulations precisely because within their jurisdiction the costs exacted from such regulations are higher than the benefits conferred. In some cases, harmonization has been coerced; in others it has been the best available response to a changed regulatory environment over which smaller jurisdictions typically have little control. Theories that rest on joint gains will seriously misspecify the mechanisms at work in these cases.

Many aspects of international regulatory harmonization are worthy of explanation. One could ask, for example, whether harmonization is likely at all or whether it is moving "up" toward more rigorous standards or "down" toward greater laxity. I address these questions only indirectly. My primary focus is on the mechanisms that drive regulatory harmonization in international finance. Just as we would like to know whether firms have arrived at similar prices for a good through collusion or competition, we want to know whether harmonization occurs through political or market pressures. My argument also informs a discussion about whether international institutions will play a role in the process of harmonization, and if so, what that role will be. In short, the dependent variable of this study is primarily harmonization processes. ${ }^{11}$ By focusing on process mechanisms, I provide a theoretical and practical explanation of the relative roles of market incentives, political pressure, and multilateral institutions in the coordination of regulatory policies.

I propose a simple framework that focuses on strategic interactions between a dominant "regulatory innovator" and the rest of the financial world. Regulatory innovation in the dominant financial center is taken as exogenous; however, the dominant regulator does have to think strategically about how foreign regulators react to its innovation. I argue that explanations for how harmonization unfolds fall into two dimensions: (1) the incentives other regulators face to emulate or diverge from the regulatory innovation of the dominant financial center, and (2) the nature and extent of the externalities produced by this reaction, as experienced in or anticipated by the dominant center. Within these two dimensions we can explain outcomes that vary across issue areas in finance, whether harmonization will be economically or politically induced, and the role, if any, played by international institutions in the process.

The framework implies that most of the regulatory harmonization that occurred in the 1980s and 1990s was not "cooperative"; it resulted less from mutual adjustment than from unilateral decisions imposed by the dominant financial centers on other jurisdictions. The decisions of regulators in the dominant centers can drastically change the choices available to other countries; they create a paradigmatic shift, and any negotiations that follow are merely splitting hairs. This does not mean that the 
United States, the United Kingdom, or even the G-10 countries always easily achieve their preferred regulatory outcome worldwide, for, as I argue, other jurisdictions may have negative reaction functions that cause them to choose divergent regulatory trajectories. In these cases, harmonization is unlikely without political pressure from the dominant financial centers. Under these conditions multilateral institutions are created to enhance political pressure.

The article is organized as follows. I first outline the basic argument and then provide evidence to show that in four issue areas illustrative of the variation in the two key explanatory variables (incentives to emulate and the nature and extent of externalities) the mechanisms of harmonization broadly accord with the expectations of the framework. I offer conclusions in the final section.

\section{Harmonizing International Capital Market Regulations}

\section{The Nature of International Finance}

Efforts over the past decade to coordinate the regulation of internationally active financial entities have been diverse and ad hoc. There is neither a single venue nor a unitary process for hammering out a regime for regulating international capital markets. No "world capital organization" parallels the World Trade Organization, nor have international rules been approached comprehensively, as was the case with the Law of the Seas during the 1970s. In fact, legally binding conventions for the international financial sector are rare (outside of Europe). Rule development has tended to involve small numbers of national regulators or supervisors, working briefly but intensively on relatively narrow issues, and producing nonbinding agreements. Arguably, the very nature of international finance has necessitated such an approach. Formal, protracted negotiations would be rapidly overtaken by technological change, financial innovation, and other market developments. Rapid changes in financial markets undercut the value of detailed, legally binding agreements that take time to ratify and implement legislatively. Overall, financial markets are swiftly moving targets whose supervision and regulation require streamlined decision making and a tremendous amount of technical expertise.

Finance is distinct in another way as well: few other areas of international activity are so profoundly dominated by only one or two countries. The United States and the United Kingdom dominate international financial issues by virtue of the size, efficiency, and internationalization of their markets and the sophistication of their regulatory structures. This dominance, in turn, is driven by the special role of the dollar and the pound sterling in international trade as well as by the extent to which firms from the United States and the United Kingdom engage in trade and foreign direct investment. Some 85 percent of world foreign exchange transactions involve the U.S. dollar, a preeminence that does not yet seem to be challenged by the euro. Moreover, firms headquartered in the United States and the United Kingdom 
accounted for 45 percent of total OECD foreign direct investment inflows and 38 percent of outflows in the 1990s. ${ }^{12}$

Finance is big business in both countries. The financial sector accounts for about 14 percent of U.S. GDP, or about $\$ 1.3$ trillion in $1998 .{ }^{13}$ The private banking sector in the United States provided domestic credit equal to 162 percent of GDP in 1998. Only Switzerland's banking sector provided a higher ratio (177 percent) but for a much smaller GDP base (the average figure for high-income countries was 140 percent of GDP). ${ }^{14}$ Institutional investors mobilize more assets in the United States and the United Kingdom than anywhere else on the globe: In the United States the ratio of these assets to GDP is 170 percent, and in the United Kingdom the ratio is 162 percent. These figures compare with 77,75 , and 46 percent respectively for Japan, France, and Germany. ${ }^{15}$ A spate of bank mergers in the late 1990s left the United States with three of the six largest internationally active banks in the world by market capitalization. ${ }^{16}$ More importantly, however, these two countries are the prime centers in which foreign financial institutions conduct business. The biggest foreign banks in the world keep more assets in the United States and the United Kingdom than anywhere else. ${ }^{17}$ London is the most highly internationalized financial center in the world, with over 550 international banks and 170 global securities houses.

The United States and the United Kingdom are also heavyweights in the financial component of international trade. Together, they exported on average during the 1990s $\$ 12.6$ billion of financial services, ${ }^{18}$ only slightly less than the total for the rest of the OECD countries combined. The United States was the second largest importer of financial services in the OECD as well (with average imports of \$2.74 billion), second only to Italy (with $\$ 3.9$ billion) and far ahead of third-place Japan (\$1.57 billion). ${ }^{19}$ Banks from the United States and the United Kingdom are also at the center of the interbank payments system: together they account for nearly half of all intra-G-10 message flows between financial institutions for purposes of

12. Thomsen 2000,6 .

13. The most specific disaggregation of the service sector conventionally available includes finance, insurance, and real estate (FIRE). See U.S. Department of Commerce 1998, tab. 601c, line 16. Available at $\langle$ http://www.lib.virginia.edu/socsci/nipa/nipa.html (accessed May 2000).

14. World Bank 2000, 260-61.

15. OECD 1997, as cited by OECD 1998, 131.

16. As of April 2000. The three U.S. banks are Citigroup, Bank of America, and Chase Manhattan. Economist, 18 April 2000, 82.

17. The twenty-five biggest foreign banks in the world keep roughly 5.6 percent ( $\$ 536$ billion) of their assets in the United States. International Banking Regulator, 29 July 1996, 4.

18. Financial intermediation services and auxiliary services between residents and nonresidents, including commissions and fees for letters of credit, lines of credit, financial leasing services, foreign exchange transactions, consumer and business credit services, brokerage services, and underwriting services.

19. OECD 2000. 
facilitating international payments. ${ }^{20}$ As a result, regulators in the United States and the United Kingdom exercise jurisdiction over financial institutions and networks that are strategically important to the global financial system as a whole.

The dominance of these two countries' banking sectors is matched, and perhaps exceeded, by their dominance in equity markets. The world's largest stock markets are located in New York and London. The U.S. stock market alone accounts for nearly 50 percent of the world's stock market valuation. ${ }^{21}$ The global market value of firms listed on the New York Stock Exchange (NYSE) and Nasdaq (the U.S. over-the-counter equities market) in 1999 was $\$ 11.4$ and $\$ 5.2$ trillion, respectively; the corresponding figure for the London Stock Exchange was $\$ 3$ trillion, and for the Tokyo exchanges was $\$ 4.5$ trillion. ${ }^{22}$ U.S. stock markets raised $\$ 14.5$ trillion for firms in the United States over the course of the 1990s. ${ }^{23}$

Exchanges in the United States and London are highly internationalized and becoming even more so. The London Stock Exchange lists companies from sixty countries, ${ }^{24}$ and the comparable figure for the NYSE is forty-nine. The number of foreign companies listed on the NYSE quadrupled between 1992 and 2000, for a current total of 400 firms. ${ }^{25}$ Meanwhile, the volume of trade in non-U.S. shares on the NYSE reached $\$ 687$ billion in $1999 .{ }^{26}$ The United States also dominates the $\$ 22$ billion international market for depositary receipts, ${ }^{27}$ accounting for three-quarters of the world total. ${ }^{28}$ With the most active exchanges in the world, North America accounts for nearly as much turnover in exchange-traded options and futures as do Europe and Asia combined. ${ }^{29}$

Finally, much of the world's financial regulatory expertise, though difficult to quantify, is concentrated in the United States and the United Kingdom. What has come to be known globally as "best practices" in supervision and regulation usually emanate from these countries (from the public regulatory apparatus, but also from the self-regulatory practices of private entities). ${ }^{30}$ It may also be significant, though

20. BIS 1998a, 136, tab. 13. The United States and the United Kingdom accounted for 240,000 settlements messages through the Society for Worldwide Interbank Financial Telecommunications (SWIFT); the rest of the G-10 combined accounted for 290,000 such messages.

21. Economist, 8 July 2000, 77.

22. New York Stock Exchange (NYSE) 1999, 3.

23. NYSE 1999, 6.

24. London Stock Exchange website, available at $\langle\mathrm{http}: / / \mathrm{www}$. londonstockexchange.com/international/default.asp $\rangle$ (accessed May 2000).

25. Economist, 17 June 2000.

26. NYSE 1999, 4.

27. Negotiable certificates issued by a U.S. bank for shares of stock issued by a foreign corporation. The securities are held in a custodial account, usually in a foreign bank (the depositary receipt itself is registered with the SEC), and give the holder the same benefits of ownership as a share holder.

28. Economist, 15 January 2000, 77.

29. Futures Industry Association Data, Bank for International Settlements.

30. As a "self-regulatory organization" the NYSE has a sophisticated computerized program for detecting suspicious trading activities and has been active in investigating activities that break its own regulations. This task is performed using Automated Search and Match (ASAM), which contains the names of 800,000 executives, lawyers, bankers, and accountants, plus public profile data on officers and directors of approximately 80,000 public corporations and 30,000 corporate subsidiaries. Between 1992 
only an indirect measure of regulatory capacity, that the Federal Reserve System produces and analyzes much more quickly the data that is relevant to understanding market trends than do central banks elsewhere. ${ }^{31}$ Since the Basel Committee for Bank Supervision came into existence in 1974, it has been chaired by a banker from either the United States or the United Kingdom for nineteen years, from the Netherlands for four years, and from Italy for four years. ${ }^{32}$ Given the strong norm of rotating power in many Eurocentric institutions, it is interesting that this committee has never been chaired by a central banker from Germany, Switzerland, France, or Japan. An American with extensive supervisory and regulatory experience was recently chosen to chair the new Financial Stability Institute, whose purpose it is to assist bank supervisors around the world in improving and strengthening their financial systems. ${ }^{33}$

\section{The Argument}

This concentration of financial power has profound implications for regulatory harmonization. The size of the internal U.S. market gives U.S. regulators an incentive to make unilateral regulatory decisions, even if foreign regulators do not follow suit. The United States is "hegemonic" in finance in the sense that it is costlier to alter its preferred regulatory innovation than to try to change the policies of the rest of the world. U.S. regulators can be thought of as unconditional first movers: financial regulatory innovation will be motivated by and respond to internal regulatory needs and politics (such as maintaining the national financial system, protecting domestic investors, improving transparency or efficiency, or securing other social or political goals). Certainly regulatory decisions are subject to competitive constraints, but the size and efficiency of U.S. financial markets and institutions often render such constraints nonbinding. The framework I develop here, therefore, takes U.S. regulatory innovation itself as an exogenous expression of the domestic political economy. Virtually every political account of financial

and 1999, 176 cases on an annual average basis were referred to hearings panels for disciplinary action. NYSE Web site 〈http://www.NYSE.com〉 (accessed May 2000).

31. According to the Economist, the Federal Reserve System is much faster at collecting and analyzing data than the European Central Bank or the Bank of Japan. Economist, 22 April 2000, 74.

32. The Basel Committee on Banking Supervision has been chaired as follows: 1974-77: Sir George Blunden (executive director of the Bank of England); 1977-88: W. P. Cooke (associate director of the Bank of England); 1988-91: H. J. Muller (executive director of de Nederlandische Bank); 1991-93: E. Gerald Corrigan (president of the Federal Reserve Bank of New York); 1993-97: T. Padoa-Schioppa (deputy director general of the Bank of Italy); 1977-1978: T. de Swaan (executive director of de Nederlandische Bank); and 1998-present: William J. McDonough (president and chief executive officer of the Federal Reserve Bank of New York). A history of the committee can be found at (http:// www.bis.org/publ/bcbsc101.pdf (accessed June 2000).

33. The FSI was formed in 1998 by the Bank for International Settlements and the Basel Committee on Banking Supervision. Its chair is John Heiman, whose resumé includes a directorship at Merrill Lynch, U.S. comptroller of the currency, the Federal Deposit Insurance Corporation, and the New York Federal Reserve. 
regulation in the secondary literature supports this assumption. ${ }^{34}$ International policies of the dominant center, however, are formulated in response to or in anticipation of the reactions of the rest of the world to a particular regulatory change.

Whatever the content of the United States' regulatory innovation, enhancement, or deregulation, it has the potential to change significantly the context for financial markets and hence it affects regulators in the rest of the world. Such a change has one of three outcomes; it may (1) provide incentives for other regulators to emulate (implying a positive reaction function), (2) provide incentives for other regulators to diverge (a negative reaction function), or (3) have no effects on others. ${ }^{35}$ One can think of this reaction function as a continuum ranging from strong incentives to defect (resembling a collaboration game) to strong incentives to emulate (resembling a coordination game). Strategic incentives in the middle of this range are undefined, because the regulatory innovation does not significantly change the conditions facing the rest of the world.

We can assess the impact of regulatory change in the dominant financial center by looking at how the innovation affects the profitability of firms operating in foreign jurisdictions. If the innovation renders nonconforming jurisdictions relatively costly or risky sites for conducting business, a logical competitive move by the jurisdiction would be to emulate the regulatory change in order to maintain or attract business. Access to the markets of the dominant financial center also provides a powerful market incentive to conform to the regulatory environment of the dominant center. In both cases, market pressures and the opportunities that follow directly from the regulatory change in the dominant center encourage harmonization. When this is the case, the dominant center can afford to take a politically passive approach to international harmonization.

Some regulatory changes, however, can prompt divergent policy choices in foreign jurisdictions. This situation occurs when a regulatory policy implemented elsewhere creates an economic incentive to respond in the opposite direction. Economic sanctions are a well-known example: a rule against providing goods or credit to a particular country in effect increases the (market) returns to those willing to defy the sanctioning coalition. Or imagine the effect on the price of a therapeutic drug in Mexico that has not been approved by the U.S. Food and Drug Administration. Assuming Mexican authorities have reached an independent conclusion regarding the safety and efficacy of the drug, they have powerful incentives to make it available, especially in light of its unavailability in the United States. In these cases the market does not reinforce the regulation of the dominant jurisdiction. On the contrary, it may raise the (opportunity) costs of harmonization.

Understanding the nature and extent of externalities is essential to understanding the dominant financial center's international policies relating to a particular innovation. The key question is whether the rest of the world's aggregate equilibrium 
reaction creates a significant negative externality for the first mover. Because the dominant center has already determined that the regulatory innovation supports its own domestic interest, no combination of responses by the rest of the world's regulators will cause it to alter its own internal regulatory stance. It will, however, anticipate costly foreign resistance to its regulations. If negative externalities are significant, the question the dominant financial center faces in formulating its international policies is how it can change the choices of other financial regulators at reasonable cost.

Suppose the world's reaction to the initial move causes a high negative externality for the first mover. Rather than meekly retracting a regulatory innovation, regulators in the dominant financial center anticipate costly foreign resistance and mobilize political pressure to change the reactions of important foreign regulators. In fact, it would be reasonable to expend political resources up to the cost of the negative externality it is importing. If the negative externality is very costly, we should see the dominant financial center exerting a good deal of political pressure. We should also observe efforts to minimize the costs of addressing these externalities. For example, if the sources of the externalities are distinct or if the externality is divisible, we could expect the United States to target its pressure accordingly. Where the source of the externality is uncertain or constantly shifting, or where the externality is not easily targeted, the dominant center might engage multilateral institutions as a more efficient way to press for regulatory change in foreign jurisdictions. However, if the negative externalities experienced or anticipated by the dominant center as a result of the reactions of the rest of the world are small, there is no reason to expect a very active international component to the regulatory change. In this case the United States should not care whether the rest of the world adopts the policy innovation.

The role of multilateral institutions flows from the hegemon's anticipation of externalities. These institutions can be created and used strategically by the dominant financial center to achieve its desired regulatory outcome-the mitigation of negative externalities - in an economical fashion. The framework predicts that their strength and role will reflect the strategic problems of the dominant center. After all, collective action problems and disagreements over distributive issues render institutions built by opposing regulatory coalitions highly unlikely. Where multilateral approaches are unnecessary to avoid externalities in the dominant center, this framework expects multilateral institutions to be weak, or at most facilitative rather than active enforcers of regulatory harmonization.

By combining these two dimensions - the extent to which foreign regulators have an incentive to emulate and the extent and nature of the externalities anticipated by the dominant financial center-it is possible to lay out the mechanisms by which harmonization is expected to occur and the role for international institutions in this process (see Figure 1).

In quadrant 1 of Figure 1 regulators in smaller jurisdictions have an incentive to emulate in a policy area when the potential negative externalities for the dominant center are high. The dominant center supports these adjustments because in the 
HIGH INCENTIVES TO EMULATE

\section{I}

SIGNIFICANT

NEGATIVE EXTERNALITIES

INSIGNIFICANT NEGATIVE EXTERNALITIES

\section{III}

\section{Dominant center pursues} unilateralism

\section{Followers adjust}

Dominant center promotes harmonization

\section{Followers adjust}

Multilateral institutional arrangements sought; information provision, technical assistance, broadbased membership

MARKET HARMONIZATION WITH INSTITUTIONAL ASSISTANCE
LOW INCENTIVES TO EMULATE

II

Dominant center promotes harmonization

\section{Followers resist}

Multilateral institutions exert political pressure; technical assistance, sanctions, broadbased membership subject to expectations of noncompliance POLITICAL HARMONIZATION THROUGH CENTRALIZED PRESSURE

IV

Minimal role for multilateral institutions; information provision, technical assistance, focal point legitimation, symbolic membership DECENTRALIZED MARKET HARMONIZATION
Dominant center pursues unilateralism

\section{Followers resist}

Minimal role for multilateral institutional arrangements

NO HARMONIZATION

FIGURE 1. Expectations: Incentives for regulatory harmonization (dominant center, followers) and likely role of international institutions

absence of harmonization it may experience negative externalities. The dominant center benefits from supporting the creation and activities of an international institution with broad-based membership encompassing the range of the sources of anticipated externalities. This institution need only play an informational role regarding the nature of the dominant financial center's standards, and may provide technical assistance to jurisdictions wishing to implement them. Although these standards may not have been preferred in the absence of the dominant center's innovation, smaller financial centers have incentives to respond by adjusting their own regulations. In this quadrant, we expect harmonization to take place primarily through market incentives and to be facilitated by the dominant financial center through an institution designed to bolster the technical ability of smaller jurisdictions to adhere.

The expectations are very different in quadrant 2 . The key difference is that smaller jurisdictions have an incentive to resist the dominant financial center's 
regulatory innovation. Moreover, their reactions create negative externalities for the dominant center. The dominant center, concerned with limiting the impact on its national firms or at home, pressures smaller jurisdictions to match its financial regulations. One way to do this is through unilateral pressure, which is a reasonable response as long as the sources of the externality are stable and distinct. In some cases the dominant financial center may be able to target or divert negative externalities at minimal cost, for example, by making bilateral agreements or taking unilateral action to mitigate the transmission of the negative externality from one jurisdiction to another. ${ }^{36}$ However, in other cases buying off one producer of a negative externality may only encourage the private entity that is the source of the externality to migrate to another jurisdiction. This is especially problematic when jurisdictions are highly substitutable for the kind of activity under consideration, and when curtailing the activity in some jurisdictions actually raises the payoffs to its few remaining (unregulated) practitioners. If these externalities cannot be targeted or diverted at reasonable cost, it is more rational for the dominant financial center to press for regulatory harmonization by creating and backing multilateral institutions that not only provide technical assistance (which would not be sufficient to convince smaller jurisdictions to harmonize their rules in this case) but also exert overt political pressure on noncompliant jurisdictions.

Since defection problems often create incentives to misrepresent behavior, multilateral institutions under these conditions will often be essential in gathering "objective" information through surveillance protocols. International institutions will also be important to the dominant financial center for coordinating potentially costly punishments that might be subject to problems of free-ridership in their absence. $^{37}$ If externalities are not divertible, or if their source is uncertain or constantly shifting (that is, if they approximate a "public bad"), we would expect membership in such an institution to be broad (with a caveat that it may be limited by a desire to include only those who can be persuaded to comply through institutional mechanisms). ${ }^{38}$ If harmonization takes place, it will be through overt political pressure from the dominant financial center, most likely exercised through a multilateral institution.

The prediction in quadrant 3 is the opposite of quadrant 2. Smaller jurisdictions have market incentives to adjust to the regulatory change in the dominant center, and the negative externalities anticipated by the financial center are minimal. Smaller jurisdictions have market motives to adjust, and the dominant center has little

36. However, as Ken Oye has noted, every diversionary agreement increases the expected negative impact that the externality will have on other jurisdictions, creating a strong incentive to strike bilateral deals with a number of foreign regulators. Oye 1992, 26.

37. Martin 1992b.

38. Downs and Rocke 1995. They argue that since enforcement of agreements can be costly, there are informational conditions under which exclusion of some "relevant" players from international agreements is reasonable, even though they may be producers of negative externalities. Uncertainty over compliance conditions any expectation of a direct relationship between the extent of externalities and the scope of participation in formal harmonization. 
incentive to respond at all. There is little reason to create an international institution in this case; harmonization is likely to proceed in a very decentralized fashion. Multilateral institutional arrangements that do develop are likely to do little more than provide technical assistance or legitimate a "focal point" that provides a multilateral veneer to an essentially unilateral decision made in the dominant financial center. ${ }^{39}$ Market forces rather than overt political pressure will foster decentralized harmonization in this case.

Finally, consider the case in which smaller jurisdictions have no incentive to adjust their regulations in response to the dominant center, yet the dominant center experiences no externalities as a result of such resistance (quadrant 4). Smaller jurisdictions do not want to emulate, but the dominant center does not care. There is no reason to expect the dominant center to invest in multilateral institutions; nor should we expect harmonization to take place under these conditions. But if it does, the mechanisms will be political rather than market based.

It is worth pointing out how this framework differs from institutionalist theories that rest on more liberal functionalist formulations. There is nothing particularly "cooperative" or even Pareto-improving about this situation. Regulators elsewhere may not even have been consulted or have participated in any meaningful way in decisions that fundamentally alter their regulatory landscape. Smaller financial centers may have had to adjust to decisions made by the United States to avoid worse outcomes, but they may have preferred no innovation by the dominant center to begin with. ${ }^{40}$ Indeed, this framework predicts an important role for coercion and persuasion when incentives to diverge are strong and negative externalities are severe. Financial dominance of the United States precludes a return to the status quo as an option, even if that is what many smaller jurisdictions would prefer.

Furthermore, by taking into account both incentives to emulate and externalities, this framework is able to provide nuanced expectations based on the strategic context that can differ markedly across issue areas in finance. Much of the literature on international institutions has been inspired by the analysis of cooperation games versus coordination games. ${ }^{41}$ Most of these analyses assume rough parity among the players and ignore the role that power and persuasion play in arriving at a stable equilibrium. In the framework here the anticipation of externalities provides the motivation for the dominant center to use political pressure to counter uncooperative behavior and to provide technical or other assistance (if necessary) to encourage emulation. It also allows for more nuanced predictions about institutional form, with shifting, uncertain, or worldwide sources of negative externalities encouraging the dominant center to invest in multilateralism.

39. This is the function that Garrett and Weingast emphasize in the case of the European Court of Justice. Garrett and Weingast 1993.

40. See, for example, Gruber 2000.

41. See Stein 1983; Snidal 1985; and Martin 1992a. Krasner notes, however, that there has been little effort to classify existing international regimes by the nature of the problem, reinforcing a tendency to emphasize prisoners' dilemmas over coordination games. Krasner 1991, 364. 
This framework differs as well from theories that expect regulatory races to the bottom. $^{42}$ There are good reasons to expect dominant financial jurisdictions to function as "regulatory anchors" in the sense that they do not respond in kind to what may seem to be competitive regulations by foreign jurisdictions. Indeed, if the dominant financial center is large and competitive enough, it seems utterly arbitrary to assume that it will sacrifice its national regulatory preferences to engage in a downward competitive spiral with foreign jurisdictions. I make the more reasonable assumption that a financial center as large and competitive as the United States is unlikely to reverse its domestically preferred regulatory course. This would not, of course, prevent races to the bottom among smaller or less-efficient jurisdictions, ${ }^{43}$ but it does provide a backstop to the generalized regulatory deterioration sometimes alluded to in the literature.

Issue areas. In this section I provide evidence for the argument. The research design is simple: I examine four issue areas of international finance that illustrate the combinations of values on the key independent variables (incentives to emulate and the nature and extent of externalities). "Financial dominance" is constant throughout these cases. The central question is whether the mechanisms of harmonization (the relative roles of market incentives and political pressures) and the role of international institutions (whether they are unimportant or central to the harmonization process; whether they are designed to facilitate, legitimate, or enforce) fit the expectations of the framework.

\section{The case of capital adequacy rules: High negative externalities, high incentives to emulate (quadrant 1)}

The globalization of banking increases the possibility that any weak bank involved in the increasingly dense network of interbank relations potentially can transmit its weaknesses throughout the international banking system. One can gain an appreciation of these linkages by looking at the size of the interbank market: for banks in countries reporting to the Bank for International Settlements (BIS), between 1983 and 1997 interbank claims averaged about 58 percent of total assets and interbank liabilities averaged about 62 percent of total liabilities. ${ }^{44}$ Furthermore, banks that are linked through the interbank market are highly leveraged, which raises "the possibility that failure of one bank to settle net transactions with other banks will trigger a chain reaction, depriving other banks of funds and preventing

42. The "race to the bottom" thesis is usually intended to convey the idea that in a competitive situation regulatory standards tend to fall below an optimal level and not that they literally crash to the level of the lowest existing national standard. The thesis is propounded in a number of issue-areas, including environmental standards (Porter 1999) and corporate law (Daniels 1991). However, for critical analysis and contrary findings in the areas of trade and finance, respectively, see D. Vogel 1995; and S. Vogel 1996.

43. See, for example, Porter 1999.

44. Bank for International Settlements Web site, 〈www.bis.org $\rangle$. 
them from closing their positions in turn." ${ }^{\circ 5}$ Capital adequacy standards are explicitly intended to "protect the safety and stability of the system as a whole"46 from risky activities of weakly capitalized firms. Highly leveraged loans linked through a transnational interbank market create a situation in which the U.S. banking system is potentially subject to the negative externalities of poor capital adequacy regulation in other parts of the world.

However, there are strong incentives to emulate a U.S. regulatory innovation involving capital adequacy standards. The fundamental reason is that international banking is characterized by information asymmetries that provide an opening for opportunistic behavior. Rules regulating capital adequacy may convey important information on the quality of a firm as a counterparty to an agreement. In this environment, appropriate prudential regulations are a competitive advantage that other jurisdictions have an incentive to copy. In the words of the chairman of the Federal Reserve Bank of Australia, once capital adequacy requirements are adopted by the Central Banks in G-10 countries, "there is considerable [market] pressure on others to follow-otherwise their banks risk being perceived as somewhat inferior institutions in competitive situations. ${ }^{, 47}$ A regulatory race to the bottom is conceivable in the absence of any obvious focal point ${ }^{48}$ but once the dominant financial center has adopted a clear standard, there is very little incentive to reduce standards and risk developing a reputation as "poorly regulated." Most banks are simply in no position to forgo reputational concerns and compete for international business on price alone. For this reason, strong incentives exist to emulate the standards adopted in the dominant financial center. Capital adequacy standards are thus illustrative of the kinds of cases that fall into quadrant 1 (see Figure 2).

Regulatory innovation in this area began in the United States in response to the savings and loans crisis of the 1980s. Worried by a trend toward capital deterioration despite growing financial risks associated with internationalization and liberalization-and the initial serious concern that differential approaches to capital requirements would constitute a competitive disadvantage for banks chartered in countries with more stringent requirements - the Federal Reserve and the Bank of England struck a bilateral agreement that provided for a common definition of capital. They agreed to adopt a risk-weighting system for each class of assets, to include "off-balance-sheet" items in risk determination, and to adopt a formula for calcu-

45. Fitch 1993, 600.

46. E. Gerald Corrigan, president of the Federal Reserve Bank of New York, statement before the U.S. Senate Committee on Banking, Housing, and Urban Affairs, 3 May 1990, as quoted by Yasushro Maehara, Comments, in Herring and Litan 1995, 154.

47. Bernard W. Fraser, governor of the Reserve Bank of Australia, remarks to the 24th Conference of Economists, Adelaide, 25 September 1995, reprinted in Reserve Bank of Australia Bulletin, October 1995. Note that this does not imply a linear relationship between higher capital adequacy standards and a reputation for safety. At some point (which even large banks and regulators would find difficult to specify) the cost of holding capital in reserve exceeds the value of the added safety and no longer contributes in any meaningful way to a safe reputation. Thus, there is little danger of an indefinite "race to the top."

48. Kapstein 1989, 324. 
HIGH INCENTIVES TO EMULATE

\section{I}

SIGNIFICANT

NEGATIVE

EXTERNALITIES

INSIGNIFICANT

NEGATIVE

EXTERNALITIES

\section{Capital adequacy}

Much "voluntary accession" to

G-10 rules

BIS as a facilitative institution

(technical expertise)

Euro-centric membership, extensive cooperative relations with regional organization of bank regulators

IMF as monitor in crisis cases

III

Accounting standards for public offerings

Much voluntary adoption of standards at the firm level (USGAAP or IAS)

IASC legitimates a "focal point" close to USGAAP

IASC provides information and technical assistance to bring accounting rules in line with international standards
LOW INCENTIVES TO EMULATE

II

Anti-money laundering

U.S. unilateral political pressure through Kerry Amendment

U.S. pressure on G-10

FATF monitors and sanctions by publicizing lax policies

FATF limits membership to OECD but sanctions nonmembers Opposition even in the OECD to U.S.-style reporting

IV

Information sharing among securities regulators

Minimal role for IOSCO (encourages bilateralism through model MOUs)

Harmonization through series of bilateral agreements

Reluctance of some major jurisdictions to cooperate

Recent move toward multilateral information-sharing agreements

FIGURE 2. Issue areas, harmonization processes, and institutional outcomes

lating specific capital requirements for individual banks based on their weightedasset risk profile. ${ }^{49}$

The case of capital adequacy standards fits the expectations of the proposed framework reasonably well. Strong market-based incentives have encouraged convergence in this area. The bilateral accord between the two largest players immediately sparked intense negotiations among the G-10 countries to adopt a common approach to capital adequacy. By some accounts, Japan, Germany, and France accepted the U.S./U.K. framework (with minor changes) because they were concerned that, without adjustment, their banks might not meet standards prevailing in the two dominant centers. ${ }^{50}$ In December 1987 central bankers from the G-10 countries adopted guidelines for evaluating the adequacy of capital in their inter- 
national banks and agreed to reach an established minimum level by 1992. By the end of 1993, internationally active G-10 banks had capital ratios that exceeded the prescribed minimum, often significantly. ${ }^{51}$

By the mid-1990s, the European Union had followed suit in their decision to use the G-10 guidelines as a basis for the Capital Adequacy Directive (CAD), which came into effect in January $1996 .^{52}$ Even more significant, a number of countries who did not participate in the G-10 process and have no obligation whatsoever to follow guidelines originating in Basel have voluntarily done so. Many developing countries have, for example, adopted the Basel Committee's 8 percent capital adequacy rule for international banks. Others have decided unilaterally to match Basel rules regarding disclosure requirements for derivatives activities, citing G-10 rules as "global standards." ${ }^{.3}$ By 1994, all 129 countries surveyed by the BIS had capital requirements of some description, and in 92 percent of cases, a Basel-like risk-weighted approach was reportedly followed. Capital charges for market risk exposure-a relatively new development-were imposed by 23 percent of the sample, and fully 85 percent of non-G-10 countries declared their intention to implement a 1995 amendment to the original 1988 Capital Accord. ${ }^{54}$ Even if these figures are exaggerated, they reflect an apparent desire to emulate the rules set forth by the G-10.

The process of rule development and dissemination has largely been market driven, though the BIS and more recently the International Monetary Fund (IMF) have played a facilitative role. Through meetings, informational conferences, and technical training courses with regional central banking organizations, the BIS has actively supported the dissemination of G-10 prudential banking regulations and standards among emerging financial markets. ${ }^{55}$ In the wake of the Asian financial crisis, banking supervisors in Indonesia have moved to phase in Basel's 8 percent capital adequacy ratio, ${ }^{56}$ despite the estimated price of recapitalization at this ratio

51. Tommaso Padoa-Schioppa, chairman of the Basle Committee on Banking Supervision, speech on Banking Supervision in a Global Market, Vienna, October 1994.

52. John Tattersall, CAD-Implementation, Foreign Exchange and Money Market, May/June 1995, 28. This has not been without some complications for the EU, since it is in the business of creating binding directives with which national legislation must be brought into conformity, a process that can barely keep up with the changes in regulatory recommendations coming from G-10 central bankers (and in fact may not be optimal given the high degree of technical uncertainty and the value of incomplete contracting in this area). Harmonization has also been complicated by the fact that the G-10 focus their attention on large banks in major money centers, whereas the EU necessarily crafts directives for national banking systems that comprise large and small banks.

53. White 1996, 22.

54. Survey results cited by Tommaso Padoa-Schioppa in his address to the 9th International Conference of Banking Supervisors, Stockholm, 12-14 June 1996.

55. See White 1996, 22; and Tommaso Padoa-Schioppa, chairman of the Basle Committee on Banking Supervision, speech on Banking Supervision in a Global Market, Vienna, October 1994.

56. All banks were to achieve a minimum capital adequacy ratio of 4 percent by the end of 1998 , rising to 8 percent by the end of 1999 , and to 10 percent by the end of 2000 . Banks that did not meet these minimum ratios were subject to sanction by the Bank of Indonesia. Available at $\langle$ www.imf.org $\rangle$ (accessed January 2000). 
of nearly 15 percent of GDP. ${ }^{57}$ Korea has also declared its intent to upgrade its prudential standards to meet the core principles of the Basel Accord and mobilized trillions of won for purposes of recapitalization with the Basel ratios in mind. ${ }^{58}$ Thailand adopted 8.5 percent recapitalization ratios for all surviving banks. ${ }^{59}$ The explicit adoption of these targets has been essential for establishing the credibility of national bank reforms. To assist in the promulgation of its standards in the region, the BIS opened its first representative office outside of its headquarters in Basel in July of 1998.

No banking supervisor in the world has been able to speak of prudential regulations without reference to "international standards" that have spread from the initial U.S.-U.K. agreement to the G-10 to the EU to a number of emerging markets. The BIS has provided technical assistance and promoted its rules as a focal point against which to judge the adequacy of banks' capital ratios in jurisdictions around the world. Despite some effort by the IMF to subject countries seeking assistance to some form of conditional adoption of these rules, ${ }^{60}$ the market pressure to meet international standards has been far more important to harmonization than organized political pressure. Capital adequacy standards have become more rigorous and more widespread than a model of competitive regulatory laxity would suggest. Just how well these rules will be implemented remains to be seen, especially in the Asian financial centers where restructuring is currently underway. But generally speaking, market pressures to match international standards have been far more important than political pressure, in sharp contrast to the case of anti-money laundering efforts, discussed in the next section.

The case of anti-money laundering rules: High negative externalities, low incentives to emulate (quadrant 2)

Money laundering supports a negative externality in the United States-criminal activity - that is extraordinarily difficult to eliminate, target, or divert. Estimates of the amount of money laundered provide an upper limit to the range of this externality: by some estimates, $\$ 1$ billion of criminal profits finds its way into the world's financial markets every day. ${ }^{61}$ Estimates of the annual amount of drug

57. Part of this figure includes repaying the Bank of Indonesia for provision of liquidity, and much is expected to be recovered as recapitalized banks are sold. Memorandum of Economic and Financial Policies, Indonesia, 10 April 1998. Available at 〈www.imf.org (accessed January 2000).

58. Korea Memorandum of Economic Policy, November 1998. Available at /www.imf.org (accessed January 2000).

59. Thailand, Memorandum of Economic Policy, 25 August 1998. Available at 〈www.imf.org (accessed January 2000).

60. Meeting Basel standards is included in every discussion of financial and economic plans among the Asian countries seeking IMF assistance, but the IMF does not consider prudential banking standards to be among its "core responsibilities" and thus collaborates with the BIS on dissemination of these principles. The IMF has, however, intensified efforts to use Art. IV consultations to promote these rules. IMF 1998.

61. Estimate given by Eduardo Vetere, head of the Crime Prevention and Criminal Justice Branch at the opening sitting of the European Regional Preparatory Meeting for the 9th UN Congress on Crime Prevention and the Treatment of Offenders (1995), Vienna, 28 February 1994. 
profits moving through the U.S. financial system have been as high as $\$ 100$ billion. ${ }^{62}$ Michel Camdessus, former director of the IMF, estimated that in 2000 the yearly global value of illicit money laundered was equal to between 2 and 5 percent of world production. ${ }^{63}$ Even if only a fraction of this total results from crimes affecting the United States, the potential negative effects are considerable. And as the recent case of the laundering of stolen aid to Russia indicates, the precedent crime does not have to be committed in the United States to frustrate broader U.S. interests. Moreover, the situation will likely deteriorate as capital controls around the world continue to loosen and the scrutiny given international transactions continues to ease. ${ }^{64}$ As evidence that the United States views money laundering as a serious threat, the U.S. Treasury Department operates the largest currency transaction reporting system in the world at an estimated cost to the banking industry as high as $\$ 136$ million annually. ${ }^{65}$

For a number of reasons, smaller jurisdictions tend not to want to emulate the tighter anti-money laundering regulations of the dominant centers. Indeed, stringent reporting requirements in the United States may make the banking secrecy offered by the legitimate private banking industry in such countries as Switzerland, Liechtenstein, and Luxembourg even more lucrative. Certainly, adopting tough reporting requirements could push funds offshore. ${ }^{66}$ Swiss officials have long recognized that bank secrecy has contributed significantly to the country's high standard of living and thus "at least indirectly concerns substantial economic interests of the state." ${ }^{, 67}$ In Liechtenstein, even mild rules regarding "due diligence"-requiring bankers to report suspicious activities to authorities-"pose a direct threat to Liechtenstein's basic competitiveness," according to bankers in Vaduz. ${ }^{68}$ Developing economies may be even more resistant. Banking secrecy combined with loose supervision may be an attractive development policy for a large number of smaller resource-poor countries and territories. In an effort to jump-start an international financial-services sector, some jurisdictions have instituted easy rules of incorporation, no recording requirements for large cash transactions, and a limited asset seizure capability. The fewer the jurisdictions willing to provide such services with minimal scrutiny, the better the terms these jurisdictions are likely to be able to extract from "investors." The conclusion in this case is quite

62. U.S. Treasury Web site /www.ustreas.gov/fincen/border.html〉 (accessed January 2000).

63. Economist, 1 July $2000,70$.

64. See testimony of the governor of the Bank of Italy, April 1989, quoted in Gurwin 1990. See also Tanzi 1996.

65. See U.S. Treasury Department Web site at /www.ustreas.gov/fincen/follow1.html〉 (accessed January 2000). This is an industry estimate. Powis 1992.

66. Lisa Troshinsky, Ex-NatWest Lawyer Fears "Know Your Customer" Fallout, International Banking Regulator, 5 August 1996, 1, 6. On the size of the private banking industry in Switzerland, see Ian Rodger, Survey of Swiss Banking, Financial Times [London], 26 October 1995, III.

67. This statement is a translation of official Swiss federal government policy, quoted in Aubert, Kernen, and Schoenle 1978, 59. (Translation from a summary generously supplied by an official of the IMF.)

68. Euromoney, July 1996, 151. 
different from that of capital adequacy regulation. Unlike the interest financial institutions may have in developing a reputation for safety, "it is not necessarily in the direct financial interest of financial institutions to adopt anti-laundering behavior."69 Anti-money laundering efforts provide no clear economic payoff, and may in fact exact immediate and unrecoverable costs to financial intermediaries.

As in the capital adequacy case, international initiatives to control money laundering have come primarily from the United States, in alliance with the United Kingdom, but also with France, and increasingly Australia. ${ }^{70}$ By 1986, the United States was the only country to have criminalized money laundering, and it remains by far the leader in prosecutions. ${ }^{71}$ Because most countries do not wish to emulate U.S. policies, and because the externalities to the United States have been high, the harmonization that has taken place has been driven by hardball political pressure. The U.S. Congress began with the "Kerry Amendment,"72 which required the U.S. Treasury to negotiate with foreign countries with the objective of having foreign banks record all cash deposits over US\$10,000 and to provide information to U.S. authorities in the event of a narcotics-related investigation. Should a bank fail to agree, the amendment gave the president the power to deny that bank access to the U.S. clearinghouse system. But for a number of reasons-including the universal nature of the problem, opposition from Treasury, ${ }^{73}$ the fear of stimulating foreign alternatives to U.S. clearinghouse facilities, and the fear of retaliation against U.S. banks - this unilateral approach fizzled with few tangible results.

The United States has had difficulty drumming up support for its anti-money laundering crusade, but with Europe's eventual support the Financial Action Task Force (FATF) was created by the OECD countries in 1989. This institution uses the only instrument at its disposal-peer pressure-to embarrass governments into adopting stricter controls over money laundering. The FATF uses a graduated set of sanctions to review and influence the policies of its own members and those of nonmembers to follow the spirit of its "Forty Recommendations" promulgated in 1990 (updated in September 1995). These recommendations call for states to ratify the 1988 Vienna Convention Against Illicit Traffic in Narcotic Drugs and Psychotropic Substances, which specifies "intentionally" laundering drug profits as a criminal activity. ${ }^{74}$ They also call on governments to adopt effective seizure and forfeiture laws and to prohibit anonymous accounts. The FATF employs a system

69. Quirk 1996, 24.

70. With one of the most technologically sophisticated methods for detecting financial patterns associated with illicit activities, Australian authorities have used their own forfeiture funds to establish a secretariat for the Financial Action Task Force (FATF) in Asia. U.S. Treasury and FINCEN officials, discussions with author, Washington, D.C., 5 and 8 August 1996.

71. Between 1991 and 1993 the number of cases filed and tried under Title 18 USC 1956 or 1957 approximately quintupled. In 1993, 822 cases were filed and 106 tried. Justice Department figures, reported in Courtenay 1994.

72. Section 4702 of the 1988 Omnibus Drug Bill. See also Crocker 1990.

73. U.S. Congress 1990, 28. This opposition was also confirmed by a U.S. Treasury official, interview with author, Washington, D.C., 7 August 1996.

74. The Vienna Convention (20 December 1988), Article 3, section 1, (b) (i) and (ii). 
of mutual review in which each member's laws and efforts are scrutinized by a FATF team and then assessed by the full membership. The mildest sanction is a letter from the president indicating shortcomings in a particular country; the harshest sanction is expulsion from the FATF. Turkey has been sanctioned-for several years it was the only country in the FATF that had failed to make money laundering a crime - and significantly changed its laws as a result. ${ }^{75}$ The FATF's "Recommendation 21 " also calls for sanctions against noncooperative nonmembers. The Seychelles was one of the first countries to be on the receiving end of such a sanction. ${ }^{76}$ The FATF routinely urges financial institutions to avoid doing business in countries with seriously inadequate money laundering laws and posts the list of such jurisdictions on its Web site. ${ }^{77}$ Meanwhile, the United States and the United Kingdom often coordinate their bilateral pressure on uncooperative jurisdictions and recently have denounced Antigua as unfit to conduct business with their national firms. ${ }^{78}$

The convergence across national jurisdictions since 1986 has been detectable but hard fought and is far from complete. Almost all industrialized countries now agree that money laundering should be considered a crime, but few countries have embraced the U.S. approach of comprehensive reporting of all cash transactions above $\$ 10,000$ (most banks have lobbied their governments hard to reject U.S.-style record keeping and reporting). ${ }^{79}$ Tightening money laundering rules continues to meet with significant resistance in much of the financially influential world. Outside of Japan, Singapore, and Hong Kong, money laundering is not a crime in much of Asia. Cooperation in the Western Hemisphere provides an interesting contrast: sustained U.S. leadership in such forums as the "Summit of the Americas" keeps laggards in the international spotlight. Many more Central and South American countries have made money laundering a crime and have even agreed to "selfassessment" (though not mutual assessment, as in the FATF) in their own regional grouping, the Caribbean Financial Action Task Force (CFATF).

75. U.S. Treasury official, interview with author, Washington, D.C., 5 August 1996.

76. In February 1996, the FATF vigorously and publicly opposed provisions of that country's "Economic Development Act," which guaranteed anonymity, immunity from criminal prosecution, and protection of all assets to anyone who invests more than $\$ 10$ million in approved investment schemes in the Seychelles. The (American) FATF president publicly termed the act "an incitement to criminals throughout the world to use the Seychelles as a clearing bank for their illegally acquired gains with full immunity." Quotations reported by AP, Worldstream, International News, dateline Paris, 1 February 1996; and in We Love the EDA, The Indian Ocean Newsletter, No. 705, 10 February 1996. Seychelles' defense of the law is reported in Mark Litchen, Storm Rages over Proposed Seychelles Investor Legislation, International Money Marketing, 16 February 1996, 17.

77. Countries currently so listed include nine island countries as well as Israel, Lebanon, Liechtenstein, Panama, Philippines, and Russia. Available at /http://www.oecd.org/fatf/pdf/AR2000-en.pdf (see Annex A, 2-10) (accessed March 2001).

78. Economist, 1 July $2000,70$.

79. R. D. Fullerton, chairman and CEO, Canadian Imperial Bank of Commerce, Toronto, Clearing out the Money Launderers, portions of a speech made before the Bankers Association for Foreign Trade Conference, reprinted in The World of Banking, September-October 1990, 5-7. 
In short, harmonization of money laundering rules depends on political pressure from the dominant financial centers. This follows from the nature of this issue-area, in which emulation has its costs and the negative externalities are high. Nor are these externalities easily controlled through unilateral efforts or by targeting individual jurisdictions. This provides incentives to create multilateral organizations with surveillance and enforcement powers. A multilateral institution, exerting strong peer pressure coordinated by the dominant centers, has been crucial to rule harmonization in this issue area.

The case of accounting standards for public offerings: Low negative externalities, high incentives to emulate (quadrant 3)

National securities regulators formulate the conditions under which companies can offer their shares to the public on stock exchanges within their jurisdiction. Yet the accounting rules used to evaluate the worth of companies so offered can vary greatly from country to country. For example, when Daimler Benz first reconciled its accounts based on "U.S. generally accepted accounting principles" (USGAAP) as a condition of listing on the NYSE, potential investors were stunned to learn that Daimler's DM615 million profit in 1993 under German accounting rules dissolved into a DM1.8 billion loss using USGAAP for the same period. ${ }^{80}$

Accounting standards for public equity offerings illustrate the conditions denoted in quadrant 3 of Figure 2. In common with capital adequacy standards, but in contrast to anti-money laundering regulations, there are significant incentives for regulators and firms to adopt the accounting rules of the dominant financial center. Because stock trading was originally influenced by time zones, this pattern is clear at the regional level. ${ }^{81}$ Thus, Canada's standards tend to resemble those of the United States, ${ }^{82}$ New Zealand's those of Australia, the Scandinavian countries' those of Germany. Such coordination is useful in the absence of global or even G-10 agreement. Disagreements emerge over which rules should be the international standard, but no national regulator has the incentive to differ radically from a major market, and once accepted, incentives to defect are virtually nonexistent. ${ }^{83}$ For internationally active firms, the transactions costs of keeping up to speed on multiple standards are likely to exceed the one-time adjustment costs to a single widely used standard regardless of its "nationality." Stock exchanges themselves want to attract

80. See The Economist Intelligence Unit, 13 May 1996; and New York Times, 31 March 1993, D8.

81. Jean-Francois Theodore, chairman and chief executive, SBF-Paris Bourse, The Emergence of Transnational Financial Zones and Prospects for Harmonization, presentation at the 20th ISOCO Conference, Paris, 11-13 July 1995.

82. SEC associate chief accountant, interview with author, Washington D.C., 13 August 1996. U.S. and Canadian accounting boards routinely coordinate their standard setting, often jointly publishing drafts and reports. See also Financial Times [London], 30 May 1996, 28.

83. One might object that there are incentives to diverge from foreign standards that are patently inferior to those currently promulgated nationally, but this is very unlikely to be the case. Major markets are only likely to develop in the presence of reasonable regulatory regimes (Sobel 1999), minimizing the theoretical possibility that small markets might have objectively justifiable reasons to prefer their accounting rules over those prevailing in a major market. 
as much high-quality foreign business as possible, making them strong proponents of international standards. ${ }^{84}$ As is the case with prudential regulations regarding bank capital, market pressures reinforce harmonization: once the adjustment costs are paid, there is no reason to buck the regulatory trend.

However, the United States experiences few if any negative externalities if other jurisdictions continue to use their own national standards for public offerings. In contrast to capital adequacy and anti-money laundering regulations, inadequate accounting rules may result in allocative inefficiency, but they are not discussed in terms of generating significant streams of negative externalities or serious systemic risks for the United States. ${ }^{85}$ Widely varying accounting rules can add to transactions costs for firms that want to offer shares on foreign exchanges, potentially deter cross-border listings (relatively few U.S. firms list on the London and Tokyo exchanges, for example) ${ }^{86}$ and confuse investors. ${ }^{87}$ Negative externalities, however, have not been central to the definition of the problem for the dominant centers.

Market dominance in equities is central to the process of harmonization. A key factor is the insistence by the Securities and Exchange Commission (SEC) that any firm listed on a U.S. exchange must use USGAAP. Market power alone has led to harmonization in this area: if companies want to list on U.S. stock exchanges, they must be willing to pay the one-time adjustment cost. Many firms have prepared their statements voluntarily in order to maximize their access to international capital. Thus, in the last few years, Swiss, French, and Belgian companies have tended to adopt USGAAP or the somewhat less stringent International Accounting Standards (IAS) currently under development by the International Accounting Standards Committee (IASC) ${ }^{88}$ In April 1996 Germany's fourth-largest company, Veba, an energy and industrial conglomerate now moving into telecommunications, adopted USGAAP; its CEO explained, "It is a global capital market, and we all have to play by the same rules." 89 A raft of European multinationals, and most of corporate Germany, including Bayer, BASF, and Hoechst, and many companies awaiting privatization, including Deutsche Telekom, may seek NYSE listings and may have

84. NYSE official, interview with author, New York, N.Y., 8 November 1995.

85. See, for example, the discussion in the introduction to Bloomer 1996.

86. Sobel 1994.

87. Michael Sharpe, chairman of the IASC, cited in International Securities Regulation Report, 26 October 1995, 1, 4. There continues to be a divide between the "British-U.S." approach and the "Continental" approach to accounting, which in turn have histories rooted in the way firms have traditionally been financed. The former stresses the shareholders' need for information about earnings and profitability and is common where capital markets have traditionally provided the major source of external financing for firms. Countries in this school include the United States, the United Kingdom, Australia, New Zealand, and the Netherlands. However, a number of countries, especially in continental Europe, use their tax books as the basis for financial reporting, which tends to mingle signals about a firm's profitability with its tax accounts and focuses on the long-term source of income rather than on profitability per se. Countries with accounting standards that fit this description include Germany, the Scandinavian countries, France, Belgium, Italy, and Spain. Cummins, Harris, and Hassett 1994, 27.

88. Michael Sharpe, chairman of the IASC, cited in International Securities Regulation Report, 26 October 1995, 1, 4.

89. Economist Intelligence Unit, 15 April 1996. 
to opt for USGAAP standards until IASC standards are complete..$^{90}$ Interestingly, the newly established Easdaq - a pan-European over-the-counter equities market established at the initiative of the European Commission-has opted to use USGAAP. ${ }^{91}$ Harmonization in accounting standards for public offerings has been decentralized and market driven toward conformity with the rules of the dominant equities market.

Because the SEC knows that firms wanting to list on U.S. exchanges are likely to be willing to pay the adjustment cost of reconciling their accounts to USGAAP, it has little incentive to foster international institutions to harmonize accounting rules. Thus, the IASC has enjoyed little support from U.S. regulators and in many respects has had to reconcile its "multilateral" rules to the demands of the SEC. After all, the IASC knows its standards have little credibility unless the SEC accepts them, and as one might expect, those rules that the SEC has accepted have been quite close to U.S. practices. ${ }^{92}$ All the while, tighter regional coordination among British and U.S. regulators outside of the IASC remains a thriving option. ${ }^{93}$ Meanwhile, Britain has opposed standardizing accounting rules at the European level. The EU has instead pursued a policy of mutual recognition, and the European Commission has formally given up any effort to create a European Accounting Standards body. ${ }^{94}$ Their strategy has been to try to influence the work of the IASC, ${ }^{95}$ a politically more palatable tactic than accepting USGAAP without any pretense of multilateralism.

Harmonization has been driven in this case by decentralized market forces, primarily the desire to access the world's most established equities markets. Firms adjust their accounts by calculating how much they would benefit from a foreign listing. Simple market power is moving harmonization toward the dominant center's preferred accounting approach. A multilateral accounting institution does exist, but it does not explain harmonization in this area. Without much active support from the United States, the IASC has provided the cover of multilateral legitimacy to mostly U.S. standards. In doing so, the IASC has provided a focal point that bears a close resemblance to SEC rules.

90. Ibid., 13 May 1996.

91. See the Easdaq rulebook, which is available at $\langle$ http://www.easdaq.com/pdf/rulebook.pdf (accessed January 2000).

92. NYSE official, interview with author, New York, N.Y., 8 November 1995.

93. U.S. standard setters, notably the Financial Accounting Standards Board (FASB), remain deeply skeptical of the IASC and continue to nurture the British-U.S. accounting alliance through the "Group of $4+1$ " countries-the United States, the United Kingdom, Australia, and Canada, plus an IASC representative. In the view of U.S. standard setters, it is crucial to continue a dialog with this group of "like-minded" standard setters and not to count on progress at the IASC, which is viewed as far more likely to promulgate stretchy rules unacceptable to the United States. The strategy of U.S. standard setters has been to make as much progress as possible in the Group of $4+1$ so that the Europeans are persuaded to participate essentially on British-U.S. terms. FASB vice chairman, interview with author, Norwalk, Conn., 15 August 1996.

94. Economist Intelligence Unit, 13 May 1996; The Financial Times [London], 6 June 1996, 29.

95. See the comments of Commissioner Mario Monti, European Commission, The Establishment of Regional Financial Areas and Perspectives on Regulatory Harmonization, presentation at the 20th Annual Meeting of IOSCO, Paris, 13 July 1995. 
The case of standards for information sharing among securities regulators: Low negative externalities, low incentives to emulate (quadrant 4)

As a consequence of the internationalization of securities and related derivatives markets, advisers in one country may routinely propose a trading strategy to a money manager in a second country that involves taking a market position in a third country while offsetting it in a derivatives market in a fourth. When trading networks cross multiple jurisdictions, regulators' efforts to access information that would expose fraudulent or highly risky trading activities are greatly complicated. Information available only to foreign regulators is often essential for a national authority to perform its functions.

To prosecute fraudulent or risky securities trading behavior, regulators often need to harmonize their rules about the release of information that may be useful for that purpose. Clearly, however, national regulators have reasons to resist making and honoring such agreements. ${ }^{96}$ Often, concerns about confidentiality are important. To assess systemic risks, national regulators need to know foreign firms' market exposure and positions. Foreign regulators, under pressure from national firms, are typically very cautious in providing such sensitive information. When a request relates to illegal activities, concerns may arise about attempts to exercise extraterritorial jurisdiction, especially if cooperation is being sought to prosecute a foreign national trading from a computer screen in his or her own country. Agreements on information sharing among regulators do not provide market incentives for emulation.

Whether or not the United States is likely to experience serious negative externalities in this issue area depends on the reasons for seeking the information. If the purpose is to prosecute securities fraud, negative externalities may exist but are likely to be limited. In this case the externality does not exhibit the same potentially global character as does money laundering, nor are there the same systemic risks posed by inadequate bank capital. When information is sought to prosecute fraud, this issue area belongs in quadrant 4 of Figure 2.

Increasingly, however, information sharing among securities regulators is viewed as crucial to detecting systemic risks. The collapse of Barings in 1995 did much to bolster this perception, even though no systemic consequences were in fact felt. Information that would have exposed Barings' dangerous aggregate position was compartmentalized in the Singapore and Osaka exchanges and not readily available to any single regulatory body. ${ }^{97}$ Revelations of how little anyone knew about Barings' total trading position is the reason regulators have begun to view information sharing as essential to establishing the actual risk

96. Special Counsel for International and Regulatory Affairs, Trading and Markets Division, Commodities and Futures Trading Commission, telephone interview with author, Washington D.C., 22 August 1996.

97. Financial Times, 19 July 1995, 7. 
position of securities firms. ${ }^{98}$ Thus, information sharing may be necessary to avert negative externalities of a more systemic nature. If so, this issue area may be migrating toward quadrant 2 .

In a simple fraud case, there are no incentives to emulate, but neither is the dominant financial center likely to experience extensive negative externalities. The framework suggests little harmonization and a minimal role for multilateral institutions. The first part of this expectation is not quite met here: the issue area is in fact characterized by a series of bilateral agreements that represent a segmented form of harmonization. The prediction for the role of multilateral institutions does hold up. The relevant institution in this case is the International Organization of Securities Regulators (IOSCO), a relatively passive organization whose primary role has been to encourage regulators to negotiate and fulfill bilateral informationsharing agreements. It also provides technical advice where necessary and offers "model agreements" to interested parties.

The dominant financial centers have proceeded bilaterally to secure understandings on information sharing for quite some time. U.S. regulators have negotiated a series of explicit bilateral information-sharing agreements, modified somewhat depending on the circumstances, across an expanding set of dyadic regulatory relationships. Pioneered by the SEC in 1986, these agreements typically take the form of bilateral memoranda of understanding (MOUs). MOUs state the intentions of the parties to make information available under certain conditions, but they are not legally binding. A typical MOU calls on each regulator to pass on information that may indicate a breach of the laws of the other party. A few MOUs grant mutual authority for on-site inspections of fund managers in each other's jurisdictions. ${ }^{99} \mathrm{By}$ the end of 1997, U.S. regulators had on record with IOSCO more than ninety bilateral MOUs and similar agreements; British regulators had forty-five; French regulators, twenty-eight; Spanish regulators, seventeen; Italian regulators, fourteen; and Japanese regulators, four. ${ }^{100}$ For reasons arising from Germany's federal structure, German securities regulators have entered into such agreements only since $1995 .^{101}$ Of the forty-nine countries whose regulatory entities have entered into information-sharing agreements, twenty-one made their first agreement with their counterpart in the United States. By the early 1990s, a number of securities regulators in emerging markets also began to develop bilateral information-sharing

98. For an interview of Simona Locatelli, Derivatives Division of the Italian Stock Exchange Council, see International Securities Regulation Report, 28 March 1996, 3, 13-14.

99. Such an agreement was signed by the SEC and the U.K. Investment Management Regulatory Organization (IMRO) in May 1995. International Securities Regulation Report, 25 May 1995, 9.

100. International Organization of Securities Regulators (IOSCO) Web site. Available at $/$ www.iosco. org $\rangle$ (accessed January 2000).

101. Prior to 1995, this was because supervision of Germany's eight exchanges was a responsibility of the federal states. The Bundesaugsichtsamt für den Wertpapierhandel (BAWe) now has the authority, but prefers to cooperate on a project-by-project basis. Georg Wittich, president, Bundesaugsichtsamt für den Wertpapierhandel, Germany, International Cooperation: The Exchange of Information Between Regulators and its Development, presentation at the 20th Annual Meeting of IOSCO, Paris, 13 July 1995. 
agreements. Securities regulators in China and Russia have now entered into such arrangements-first and foremost with the SEC. ${ }^{102}$

Clearly, there are some moderate externalities associated with the prosecutorial practices in other jurisdictions, but in this case, externalities are easy to target on a bilateral basis, and prior to the Barings case were perceived to have no important systemic consequences. This explains the institutional response: bilateral agreements are easier to negotiate than multilateral accords and minimize defection through specific reciprocity. As securities markets globalize, the incentive to replicate information-sharing agreements increases while the transaction costs of doing so decline (there are numerous tested "models" from which to select). Jurisdictions that transact a high volume of business repeatedly invoke particular bilateral arrangements, such as those between the United States and the United Kingdom. ${ }^{103}$ The key point here is that negative externalities are easily targeted; it makes sense in this case to negotiate agreements that constitute bilateral "club goods" that provide benefits (mutual access to information) for members only. Broad multilateral cooperation, particularly in the prosecution of illegal practices, is not as important to the dominant financial centers as having clear agreements with a few key regulators or exchanges.

Only recently have multilateral information-sharing agreements been made, and as the framework presented here suggests, these aim primarily to facilitate the detection of systemic risks that pose potentially far greater negative externalities for the dominant financial center. In March 1996 some forty-nine exchanges and clearinghouses (fourteen of which are in the United States), as well as fourteen regulatory agencies, signed international information-sharing agreements that informally commit signatories to share market and financial information about members. ${ }^{104}$ The expressed purpose is to allow a more comprehensive assessment of the intermarket risks. Thus, systemic concerns are beginning to make cooperation among securities regulators more closely resemble that among banking regulators. Arguably, this case migrated from the lower to the upper region of quadrant 4 after 1995 , indicating that harmonization of information-sharing arrangements among securities regulators depends on the purposes to which the information will be put. Increasingly, these purposes involve averting potential systemic risks.

102. Russian regulators' first such agreement and Chinese regulators' second (after one with Hong Kong authorities) are with the SEC. Both concern technical cooperation, mutual assistance, and consultation between the SEC and the Russian and Chinese counterparts. Available at /www.iosco.org (accessed January 2000).

103. Special Counsel for International and Regulatory Affairs, Trading and Markets Division, Commodities and Futures Trading Commission, telephone interview with author, Washington, D.C., 22 August 1996.

104. Japan's national regulatory structures did not allow Japanese authorities to sign the agreement, triggering criticisms that its national laws were hampering international cooperation. Italian regulators signed, but the Italian stock exchanges could not because engaging in surveillance of their members is not allowed. The MOU does, however, allow signatories to join the agreement at a later date, which Japan was expected to do. See International Securities Regulation Report, 28 March 1996, 1, 8. 
The framework predicts little role for a multilateral institution in this issue area. After all, the segmented and targetable nature of the externalities arising from illegal trades make bilateral arrangements more cost effective than broad multilateral approaches. As expected, IOSCO has been passive; its purpose is not to enforce MOUs or even to publicize the extent of their use or patterns of compliance. Its innocuous role is reflected in its membership, which is ridiculously broad and practically little more than symbolic: about 95 percent of the world's exchanges belong. ${ }^{105}$ In this issue area, enforcement is enhanced by bilateralism, which has the capacity to customize obligations and make expectations explicit, thus reducing defection, yet allows for face-saving ways to exit from an agreement. As systemic concerns and the potential for negative externalities have increased, however, the SEC and major U.S. exchanges have been willing to engage in multilateral commitments to share information on firms' trading positions.

\section{Conclusions}

Capital markets have developed so rapidly over the past two decades that regulators have struggled to keep pace with the changing markets they supervise. Across the regulatory spectrum, from bank supervision to securities regulation, from accounting requirements to anti-money laundering efforts, national authorities are finding that the ability to achieve their objectives at a reasonable cost is influenced by the actions (or inaction) of their counterparts in foreign jurisdictions.

Power and influence in international finance are so asymmetrical that we can understand the mechanisms of rule harmonization and the role of international institutions in this process using a fairly simple framework. Essentially, once the dominant financial center initiates a regulatory innovation (which is exogenous to the framework and is assumed to be determined by the domestic political economy), it is important to know two things: first, whether other jurisdictions have incentives to emulate or to resist the change; and second, whether negative externalities experienced by the dominant center are easily targeted or diverted. The first condition explicitly acknowledges that foreign regulators' utilities can be either positively or negatively correlated with the dominant financial center's regulatory innovation. If the utility of the foreign jurisdiction is positively correlated with emulating the rules of the dominant center, harmonizing will occur. If the utility is negatively correlated, the jurisdiction may have incentives to implement regulations that run counter to those in the dominant center in order to collect a premium for offering services foreclosed by the regulatory innovation in question. Harmonization, if it is to occur, will require mechanisms that involve the use of political pressure, coordinated by the dominant financial center. 
Externalities are central to this framework because they determine whether regulators in the dominant jurisdiction have an incentive to pressure other regulators to conform. Thus, they are central to assessing whether harmonization processes flow from the market or from overt political pressure by the dominant center. Moreover, we expected weak or merely symbolic international institutions when the dominant center experiences few negative externalities as a consequence of its innovation. In this case the dominant center has little reason to invest heavily in institutional infrastructure, and in the absence of such investments international institutions are not likely to be central to the harmonization process.

As the application of the model developed, it became clear that it is also important to know whether negative externalities imported by the financial center are easily targeted or diverted. When they are not, broad multilateral institutions may play an important role in harmonization (subject to concerns about noncompliance when market incentives are absent). But when they are, bilateral arrangements can be effective without the dominant center expending resources to achieve compliance among a broad heterogeneous membership. When there is no market incentive for other jurisdictions to match the regulatory change in the dominant financial market, and this incentive leads to choices that impart negative externalities to the dominant center, international institutions are not only likely to be multilateral. They are expected to perform important surveillance and sanctioning functions as well.

This simple framework explains reasonably well the mechanisms through which harmonization occurs and the role, if any, played by international institutions in this process. It explains, for example, why a surprising number of national banking supervisors have been willing to adopt the capital adequacy standards in the Basel Accord: in an uncertain and asymmetrical information environment markets virtually demand it as an indicator of a "well-regulated" jurisdiction. The dominant financial centers support the role of the BIS to disseminate information and provide technical assistance about these standards.

The framework also explains why harmonization of anti-money laundering rules has been a slow, partial, painful, and highly politicized process. Emulation in this issue area is costly, yet the United States is determined to address crime at home by enlisting often reluctant foreign jurisdictions to help ensure that crime does not pay. The United States has been central to the creation of an institution-the FATF- that can pass judgment on and sanction both members and nonmembers.

The case of accounting standards for public offerings provides a good example of incentives to emulate and low negative externalities for the United States. Predictably, market forces have fueled harmonization, and the efforts of the IASC have largely served to provide international legitimation for standards very close to those insisted on by the SEC.

The most uncomfortable fit for the framework is explaining the outcome for information-sharing rules among securities regulators. In retrospect, I probably underestimated the externalities associated with foreign regulators' unwillingness to cooperate in prosecutions of fraud by providing essential information to the SEC. While limited, the externalities are not likely to be zero. Moreover, U.S. regulators 
have found a relatively low-cost way to address what is essentially a private negative externality: strike a series of informal bilateral deals with the most significant jurisdictions and rely on specific reciprocity for enforcement. Increasingly, as information sharing has been needed to assess systemic risks with broader indivisible negative externalities, agreements have become more multilateral in their scope and more institutionalized in their provisions, as the framework would predict.

The attractiveness of this framework in explaining regulatory harmonization generally will depend on its ability to "travel" convincingly to other issue areas. The strong asymmetry among financial jurisdictions may at first seem somewhat inappropriate for other issues, such as environmental or labor regulations. Yet on closer examination it may not be inappropriate. The dominance of the financial center in this framework serves to remind us that large jurisdictions take actions that correspond to their nationally determined preferences, and that these regulatory choices are not likely to be retracted simply because other jurisdictions have not chosen to emulate. It seems reasonable to assume that asymmetries are significant enough in a number of other areas to warrant such an assumption. Across a range of regulatory cases it should be possible, in principle, to assess whether the choices made by a dominant jurisdiction provide incentives to others for emulating or diverging or make no difference at all. Furthermore, whether or not the externalities are strongly negative enough for the dominant jurisdiction to respond with political pressure seems to transfer readily to other regulatory domains. The real difficulty in applying this approach is the difficulty inherent in specifying in advance just how costly a negative externality is likely to be in any given issue area. How, for example, can one rigorously quantify the (potential) externality imposed on the United States if other jurisdictions do not follow Basel standards of prudential banking supervision? Economists might be able to offer a theoretical response having to do with the cost of returning to the status quo, but actually measuring externalities will often be extremely complex.

Nonetheless, the framework offered here suggests two crucial dimensions within which we can understand the mechanisms behind observed regulatory harmonization. The first dimension comprises the incentives smaller jurisdictions have to emulate changes made by regulators in major markets. These incentives vary by issue area, as the research presented here reveals. This variability is one reason competitive races to the bottom occur with less frequency than some analysts expect: powerful market players often prefer standards that, in some cases, give foreign regulators a market incentive to match rather than to undercut. The second important dimension comprises the nature and extent of externalities that affect a dominant jurisdiction. When externalities are significant, the dominant actor can use unilateral political coercion to press for harmonization or can shape the role and strength of international institutions to mitigate "public" negative externalities and to enforce cooperative behavior. Neoliberal institutionalism to date has not provided a convincing explanation for the kinds of institutional variations this framework addresses. Moreover, analyses inspired by liberal functionalist approaches have 
played down important differences between market pressures and political pressures to harmonize policies and have emphasized joint gains while submerging the more coercive aspects of "cooperative" arrangements. This framework provides a way to analyze systematically the incentives of both the dominant jurisdiction and less powerful but potentially significant producers of externalities elsewhere. As such, it helps to make sense of a bewildering array of agreements, institutional arrangements, and unilateral practices designed to address the problems posed by rapidly changing international capital markets.

\section{References}

Aubert, Maurice, Jean-Philippe Kernen, and Herbert Schonle. 1978. Das Schweizerische Bankgeheimnis. Bern: Stampfli.

Bank for International Settlements (BIS). Various years. International Banking and Financial Market Developments. Basle: BIS.

1996. Central Bank Survey of Foreign Exchange and Derivative Market Activity. Basle: Bank for International Settlements, Monetary and Economic Department.

- 1998. Statistics on Payments Systems in the Group of Ten Countries: Figures for 1997. Available at 〈http://www.bis.org/cpss29.pdf〉.

- 1998. Central Bank Survey of Foreign Exchange and Derivative Market Activity. Basle: Bank for International Settlements, Monetary and Economic Department.

. 1999. Trading in Derivatives Disclosures of Banks and Securities Firms: Results of the Survey of Public Disclosure in 1998 Annual Reports. Joint Report of the Basel Committee of Banking Supervisors and the Technical Committee of the IOSCO. Basel Committee Publication No. 64. Available at $\langle$ http://www.bis.org/publ/bcbs64.htm\#pgtop〉 (accessed March 2001).

Bloomer, Carrie, ed. 1996. The IASC-US Comparison Project: A Report on the Similarities and Differences Between IASC Standards and USGAAP. Norwalk, Conn.: Financial Accounting Standards Board.

Cerny, Philip G. 1993. The Deregulation and Re-regulation of Financial Markets in a More Open World. In Finance and World Politics: Markets, Regimes, and States in the Post-hegemonic Era, edited by Philip G. Cerny, 51-85. Brookfield, Vt.: Edward Elgar.

Courtenay, Adam. 1994. The Buck Never Stops. The Banker 144 (November):88-89.

Crocker, Thomas. 1990. Bankers, Police Yourselves. International Financial Law Review 9 (6):10-11.

Cummins, Jason G., Trevor S. Harris, and Kevin A. Hassett. 1994. Accounting Standards, Information Flow, and Firm Investment Behavior. NBER Working Paper No. 4685. Cambridge, Mass.: National Bureau of Economic Research.

Daniels, Ronald J. 1991. Should Provinces Compete? The Case for a Competitive Corporate Law Market. McGill Law Journal 36 (1):130-90.

Downs, George W., and David M. Rocke. 1995. Optimal Imperfection? Domestic Uncertainty and Institutions in International Relations. Princeton, N.J.: Princeton University Press.

Fitch, Thomas P. 1993. Dictionary of Banking Terms. 2d ed. New York: Barrons.

Garrett, Geoffrey, and Barry R. Weingast. 1993. Ideas, Interests, and Institutions: Constructing the European Community's Internal Market. In Ideas and Foreign Policy, edited by Judith Goldstein and Robert O. Keohane, 173-206. Ithaca, N.Y.: Cornell University Press.

Gruber, Lloyd Gerard. 2000. Ruling the World: Power Politics and the Rise of Supranational Institutions. Princeton, N.J.: Princeton University Press.

Gurwin, Larry. 1990. 1992 Means a Single Market for Crime, Too. Global Finance 4 (1):48.

Herring, Richard J., and Robert E. Litan. 1995. Financial Regulation in the Global Economy. Washington, D.C.: Brookings Institution. 
International Monetary Fund (IMF). 1998. Report of the Managing Director to the Interim Committee on Strengthening the Architecture of the International Monetary System. October 1. Available at 〈www.imf.org/external/np/omd/100198.htm〉. 1999. World Economic Outlook Database. Washington, D.C.: IMF.

Kapstein, Ethan B. 1989. Resolving the Regulators' Dilemma: International Coordination of Banking Regulations. International Organization 43 (2):323-47.

Keohane, Robert O. 1984. After Hegemony: Cooperation and Discord in the World Political Economy. Princeton, N.J.: Princeton University Press.

Krasner, Stephen D. 1991. Global Communications and National Power: Life on the Pareto Frontier. World Politics 43 (3):336-66.

Martin, Lisa L. 1992a. Interests, Power, and Multilateralism. International Organization 46 (4):765-92. 1992b. Coercive Cooperation: Explaining Multilateral Economic Sanctions. Princeton, N.J.: Princeton University Press.

New York Stock Exchange (NYSE). 1999. The Year 1999 in Review. Available at (http:// www.NYSE.com/pdfs/intro99.pdf) (accessed May 2000).

Oatley, Thomas, and Robert Nabors. 1998. Redistributive Cooperation: Market Failure, Wealth Transfers, and the Basle Accord. International Organization 52 (1):35-54.

OECD. 1997. Institutional Investors Statistical Yearbook 1997. Paris: OECD.

1998. OECD Economic Survey: United Kingdom. Paris: OECD.

2000. Financial Market Trends, No. 5 (March):28. Available at 〈http://www.oecd.org/daf/ financial-affairs/markets/FMT75Cross-Border.pdf (accessed May 2000).

Oye, Kenneth A. 1992. Economic Discrimination and Political Exchange: World Political Economy in the 1930s and 1980s. Princeton, N.J.: Princeton University Press.

Pahre, Robert. 1999. Leading Questions: How Hegemony Affects the International Political Economy. Ann Arbor: University of Michigan Press.

Porter, Gareth. 1999. Trade Competition and Pollution Standards: "Race to the Bottom" or "Stuck at the Bottom"? Journal of Environment and Development 8 (2):133-51.

Powis, Robert E. 1992. Money Laundering: Problems and Solutions. The Banker 175 (6):52-56.

Quirk, Peter J. 1996. Macroeconomic Implications of Money Laundering. Working Paper 96/66. Washington, D.C.: IMF, Monetary and Exchange Affairs Department.

Reinicke, Wolfgang H. 1995. Banking, Politics, and Global Finance: American Commercial Banks and Regulatory Change, 1980-1990. Brookfield, Vt.: Edward Elgar.

Snidal, Duncan. 1985. Coordination Versus Prisoners' Dilemma: Implications for International Cooperation and Regimes. American Political Science Review 79 (4):923-42.

Sobel, Andrew C. 1994a. Domestic Choices, International Markets: Dismantling National Barriers and Liberalizing Securities Markets. Ann Arbor: University of Michigan Press.

1994b. Breaching the Levee, Waiting for the Flood: Testing Beliefs About the Internationalization of Securities Markets. International Interactions 19 (4):311-38.

. 1999. State Institutions, Private Incentives, Global Capital. Ann Arbor: University of Michigan Press.

Stein, Arthur A. 1983. Coordination and Collaboration: Regimes in an Anarchic World. In International Regimes, edited by Stephen Krasner, 115-40. Ithaca, N.Y.: Cornell University Press.

Strange, Susan. 1996. The Retreat of the State. New York: Cambridge University Press.

Tanzi, Vito. 1996. Money Laundering and the International Financial System. Working Paper 96/55. Washington, D.C.: IMF, Fiscal Affairs Department.

Thomsen, Steven. 2000. Investment Patterns in a Longer-Term Perspective. OECD Directorate for Financial, Fiscal, and Enterprise Affairs, Working Papers on International Investment, No. 2000/2, April. Available at $\langle\mathrm{http} / / \mathrm{www} .0 e c d . o r g / d a f / i n v e s t m e n t / f d i / w p 20002 . p d f\rangle$ (accessed May 2000).

U.S. Congress. House Subcommittee on Narcotics, Terrorism, and International Operations. 1990. Drug Money Laundering, Banks, and Foreign Policy: A Report to the Committee on Foreign Relations, United States Senate. 101 st Cong., 2d sess. 27 September, 4 October, 1 November. Washington, D.C.: U.S. Government Printing Office. 
U.S. Department of Commerce, Bureau of Economic Analysis. 1998. National Income and Product Accounts of the United States, 1924-94. Washington, D.C.: U.S. Government Printing Office. Available at $\langle$ http://www.lib.virginia.edu/socsci/nipa/nipa.html〉 (accessed January 2000).

Vogel, David. 1995. Trading Up: Consumer and Environmental Regulation in a Global Economy. Cambridge, Mass: Harvard University Press.

Vogel, Steven Kent. 1996. Freer Markets, More Rules: Regulatory Reform in Advanced Industrial Countries. Ithaca, N.Y.: Cornell University Press.

White, William R. 1996. International Agreements in the Area of Banking and Finance. Paper presented at the Monetary and Financial Integration in an Expanding (N)AFTA: Organization and Consequences conference, Toronto, Ontario, 15-17 May.

World Bank. 2000. Entering the 21st Century: World Development Report 1999/2000. Available at 〈http://www.worldbank.org/wdr/2000/ (Accessed May 2000). 